\title{
Mengupas Bentuk Dilema Dari Sisi Konsultan Pajak
}

\author{
Anak Agung Istri Pradnyarani Dewi ${ }^{1}$ \\ Made Sudarma ${ }^{2}$ \\ Zaki Baridwan ${ }^{3}$ \\ ${ }^{1,2,3}$ Fakultas Ekonomi dan Bisnis, Universitas Brawijaya, Indonesia \\ email: aipradnyarani@gmail.com
}

DOI: https://doi.org/10.24843/JIAB.2019.v14.i01.p12

\section{Jurnal Ilmiah Akuntansi dan Bisnis (JIAB)}

https://ojs.unud.ac.id/index.php/jiab/ user/profile

Volume 14

Nomor 1

Januari 2019

Halaman 132-141

p-ISSN $\underline{2302-514 X}$

e-ISSN $\underline{2303-1018}$

\section{INFORMASI ARTIKEL}

Tanggal masuk: 18 September 2018

Tanggal revisi:

26 November 2019

Tanggal diterima:

12 Desember 2019

\begin{abstract}
ABSTRAK
Penelitian bertujuan mengupas bagaimana bentuk dilema yang di alami konsultan pajak serta pengalaman konsultan pajak dalam mengatasi dilema yang dirasakan terutama ketika melakukan tax planning. Metode penelitian yang digunakan yaitu kualitatif dengan paradigma intepretif dan pendekatan fenomenologi transendental Husserl. Informan dalam penelitian adalah konsultan pajak IKPI Kota Denpasar. Hasil penelitian mengungkap bentuk-bentuk dilema konsultan pajak, seperti dilema yang muncul akibat konsultan pajak memiliki kepedulian terhadap kliennya dan konsultan pajak memikirkan keberlangsungan bisnis jasanya. Bentuk-bentuk dilema tersebut menghasilkan pengalaman konsultan pajak dalam mengatasi dilema yang dirasakan yaitu dengan cara membangun kesadaran dari wajib pajak serta harus mempunyai kesadaran profesi sebagai konsultan pajak yang terikat dengan kode etik. Dilema dapat diatasi dengan membangun kesadaran wajib pajak serta mempunyai prinsip yang kuat untuk mematuhi kode etik.
\end{abstract}

Kata kunci: Dilema etis, konsultan pajak, tax planning, kepatuhan wajib pajak, fenomenologi

\section{A Phenomenological Study of The Dilemmas Faced by A Tax Consultant}

\begin{abstract}
This study aims to explore how the natural shape of the dilemmas in tax consulting and how the experience of overcoming dilemmas, is felt especially when doing tax planning. The qualitative method has been used with the interpretive paradigm according to the approach of transcendental phenomenology of Husserl. The informant in this study is a tax consultant of IKPI Denpasar. The research results reveal that dilemma forms tax consultants such that the dilemma posed by tax consultants have concern for the client and tax consultants think of business continuity services. The dilemma forms generate tax consulting experience in overcoming the perceived dilemma that is by building awareness of the taxpayer and must be aware of the profession as a tax consultant who is bound by the code of conduct. The dilemma can be overcome by building awareness of taxpayers and having strong principles to comply with the code of ethics.
\end{abstract}

Keywords: Ethical dilemma, tax consultants, tax planning, tax payer compliance, phenomenology 


\section{PENDAHULUAN}

Konsultan pajak merupakan profesi seseorang yang membantu wajib pajak secara professional dalam pemenuhan kewajiban perpajakan sesuai dengan peraturan perundang-undangan. Konsultan pajak memiliki kode etik yang berfungsi untuk menjaga profesionalisme, integritas dan independensinya dalam melakukan tugasnya. Namun, disisi lain keahlian konsultan pajak dapat disalahgunakan oleh wajib pajak. Wajib pajak khususnya wajib pajak badan akan memaknai pajak sebagai pengurang dari laba perusahaannya. Mengatasi hal tersebut wajib pajak badan dapat melakukan tax planning. Tax planning dikategorikan menjadi dua yaitu legal dan ilegal. Tax planning legal menggunakan cara memanfaatkan celah-celah dalam peraturan, sehingga tax planning yang dilakukan masih dalam lingkup undang-undang. Sedangkan tax planning ilegal merupakan cara yang dengan sengaja menggelapkan pajak, melaporkan data-data yang tidak benar, bahkan tidak melaporkan pajak. Tax planning sesungguhnya bukan suatu hal yang terlarang, namun dalam sisi etis tax planning bertentangan dengan maksud dari undang-undang (Suryowati, 2016).

Fenomena yang terjadi saat ini adalah wajib pajak sedang marak melakukan praktik tax planning dari yang normal hingga kearah agresif. Wajib pajak kerap meminta bantuan konsultan pajak dalam pembuatan tax planning. Hal tersebut disebabkan karena kurangnya pemahaman wajib pajak akan rumitnya peraturan perpajakan sehingga wajib pajak lebih memilih menggunakan jasa konsultan pajak untuk membantunya dalam pembuatan tax planning perusahaannya. Erard (1993) mengungkapkan bahwa melalui konsultan pajak, wajib pajak memiliki peluang memanfaatkan konsultan pajak untuk melakukan ketidakpatuhan. Wajib pajak kerap mengiming-imingi konsultan pajak dengan imbalan yang diberikan, serta menarik rasa simpati konsultan pajak dengan berbagai alasan yang diucapkan, sehingga menempatkan konsultan pajak dalam dilema.

Setiap profesi memiliki suatu dilema saat melakukan tugasnya, begitu pula dengan konsultan pajak. Massie (2017) berpendapat bahwa diantara profesi lainnya, konsultan pajak lebih memiliki sensitifitas etika yang tinggi. Dilema yang dirasakan konsultan pajak adalah dimana konsultan pajak harus tunduk dengan peraturan namun disisi lain konsultan pajak memikirkan faktor imbalan yang diberikan wajib pajak serta kelangsungan bisnis jasanya (Suardika, 2016). Hal tersebut menghadapkan konsultan pajak untuk mempertimbangkan suatu keputusan etis untuk mengakhiri dilema yang dirasakan.

Penelitian terdahulu tentang dilema dan pengambilan keputusan etis konsultan pajak telah banyak dilakukan, namun masih lebih banyak di ranah positivis sehingga tidak secara mendalam mengetahui bagaimana dilema yang dirasakan dan bagaimana konsultan dapat mengambil suatu keputusan etis. Seperti penelitian dari Windesi (2016) menguji pengaruh faktor-faktor internal individual yang ada dalam diri akuntan pajak terhadap pengambilan keputusan etis dalam perencanaan pajak. Faktorfaktor tersebut yaitu persepsi pentingnya etika dan tanggung jawab sosial, sifat machiavellianisme dan locus of control. Penelitian Katuuk, Manossoh, \& Walandouw (2017) dimana menguji pengaruh integritas dan kreativitas konsultan pajak terhadap kepatuhan Wajib Pajak. Penelitian fenomenologi sendiri tentang dilema dilakukan oleh Noviriani (2015) dimana membahas mengenai bagaimana bentuk dilema etis auditor pemerintah dan bagaimana cara auditor tersebut memecahkan dilema etis yang dirasakan.

Beberapa penelitian terdahulu tersebut membuat peneliti merasa tertarik untuk melakukan penelitian pada konsultan pajak yang terdaftar pada IKPI Kota Denpasar dengan menggunakan studi fenomenologi untuk lebih mendalami dilema dan pengambilan keputusan etis yang dilakukan konsultan pajak untuk mengatasi dilema yang dirasakan. Menggunakan fenomenologi transcendental Husserl, peneliti meyakinkan untuk mendapatkan hasil lebih dalam dan murni dari pernyataan Informan. Fenomenologi transcendental Husserl memiliki konsep epoche yang berarti pengurungan pengetahuan yang dimiliki peneliti sehingga dapat diperoleh pernyataan murni dari Informan yang dalam penelitian ini adalah konsultan pajak. Kuswarno (2009) menjelaskan bahwa fenomenologi transcendental memiliki beberapa tahapan analisis yaitu; kesenjangan, noema dan noesis, intuisi, serta intersubjektifitas. Kesenjangan dalam hal ini adalah orientasi informan terhadap suatu objek dan didasari oleh minat, harapan dan penilaian awal. Noema merupakan pernyataan awal yang diungkapkan dapat berupa suatu ide-ide. Noesis merupakan action dari ide yang di temukan. Intuisi merupakan suatu hal yang menghubungkan antara noema dan noesis, serta intersubjektif merupakan suatu realitas sosial yang dimaknai secara bersama-sama. Penelitian di ranah positivis tidak mendalami apa yang dirasakan konsultan pajak secara murni. Sehingga sangat menarik jika mendalami pengalaman konsultan pajak dalam mengatasi dilema dengan menggunakan fenomenologi transcendental. 


\section{METODE PENELITIAN}

Penelitian ini menggunakan metode kualitatif dengan paradigma intepretif dan pendekatan fenomenologi transcendental. Paradigma intepretif bertujuan untuk menggali pengalaman informan atas fenomena yang dialami dimana dalam penelitian ini adalah pengalaman konsultan pajak atas dilema etis yang dirasakan. Menggunakan pendekatan fenomenologi transcendental bertujuan untuk mendalami pengalaman informan secara murni tanpa ada campur tangan peneliti. Informan dalam penelitian ini adalah konsultan pajak yang terdaftar di IKPI di Kota Denpasar. Pemilihan informan harus secara cermat dan tepat. Ketepatan dalam memilih informan akan menghantarkan peneliti pada keberhasilan dalam penelitiannya. Peneliti menggunakan teknik pemilihan informan yang paling umum digunakan adalah teknik snowball. Teknik snowball informan dipilih berdasarkan rekomendasi orang ke orang yang sesuai dengan pertanyaan penelitian untuk diwawancarai (Putu, 2009). Peneliti meminta rekomendasi calon informan dari salah satu Infroman kunci. Selanjutnya peneliti meminta rekomendasi informan lainnya yang sesuai dengan karakteristik penelitian ini (Fitriani, 2014). Informan dalam penelitian ini merupakan informan yang menurut pertimbangan peneliti merupakan orang yang cocok dan berkaitan dengan penelitian ini, yaitu lima konsultan pajak Kota Denpasar yang terdaftar dalam IKPI dan mempunyai pengalaman di atas tiga tahun.

\section{Tabel 1. Daftar Informan}

\begin{tabular}{llll}
\hline No & \multicolumn{1}{c}{$\begin{array}{c}\text { Nama Konsultan } \\
\text { Pajak }\end{array}$} & \multicolumn{1}{c}{ Pengalaman } & \multicolumn{1}{c}{ Alamat } \\
\hline 1. & Informan K. D & 2008-sekarang & Jl. Kenyeri Denpasar \\
2. & Informan R. Z & 2009-sekarang & Jl. Kecubung Denpasar \\
3. & Informan K. R & 2012-sekarang & Jl. Gemitir Denpasar \\
4. & Informan M & 2010-sekarang & Jl. Suli Denpasar \\
5. & Informan W & 2005-sekarang & Jl. Tukad Buaji \\
& & & Denpasar \\
\hline
\end{tabular}

Hal terpenting selanjutnya sebelum melakukan analisis data dilapangan peneliti terlebih dahulu melakukan tahapan-tahapan pengumpulan data pada penelitian fenomenologi yang diilustrasikan oleh Creswell (2016). Tahap pertama adalah penentuan lokasi dan mendapatkan akses serta membuat kesepakatan. Selanjutnya, peneliti membuat janji pertemuan selanjutnya dengan informan untuk melakukan pengumpulan data. Peneliti masuk kedalam pengumpulan data melalui wawancara. Dalam proses wawancara peneliti terlebih dahulu dilakukan dengan "mengurung" pengetahuan yang dimiliki agar informasi yang diperoleh murni dari pengalaman informan. Proses ini disebut epoche. Selanjutnya, peneliti merangkum garis-garis besar dari hasil wawancara yang dilakukan secara sistematis. Peneliti dalam menyesuaikan hasil dengan pertanyaan, peneliti memilah-milah data yang dianggap penting dan juga mengkelompokan data yang dianggap sama, agar lebih mudah dalam melakukan analisis nantinya.

Teknik analisis data yang digunakan dalam penelitian ini mengacu teknik analisis oleh Sanders (1982). Tahapan pertama, peneliti mendeskripsikan fenomena yang terlihat dari pernyataan informan. Tahapan kedua, peneliti memilah tema dan mengindentifikasi tema yang terlihat dari pernyataan informan. Tahapan ketiga, peneliti mengembangkan hubungan antara noema noesis yang diungkapkan oleh informan. Tahap keempat, proses reduksi eideitic dimana reduksi ini akan mengungkap struktur dasar dari makna yang diperoleh dengan menggunakan refleksi dan intuisi. Peneliti menambahkan satu tahap terakhir, yaitu proses pengambilan sintesis makna dari pernyataanpernyataan informan (Kuswarno, 2009).

\section{HASIL DAN PEMBAHASAN}

Bentuk Dilema: Rasa simpati Terhadap Klien. Setiap individu dilahirkan untuk mempunyai rasa saling peduli terhadap individu lainnya. Seorang yang berprofesi sebagai penyedia jasa konsultan pun demikian. Konsultan pajak adalah seseorang yang paling dekat dengan wajib pajak, serta memiliki tugas 
untuk membantu wajib pajak jika mengalami kesulitan dalam hal perpajakan. Seperti yang diungkapkan oleh Frecknall-Hughes \& Krichler (2015) dimana mengatakan bahwa konsultan pajak dapat memahami wajib pajak, motivasi wajib pajak, serta keinginan wajib pajak dalam urusan perpajakannya (Mangoting, 2017). Wajib pajak di sisi lain memiliki sifat-sifat yang berbeda dan tentunya dapat mempengaruhi sikap konsultan pajak. Konsultan pajak tentunya harus berlandaskan sesuai aturan saat melakukan tugastugasnya. Begitu pula dalam hal tax planning.

Sebagai seorang konsultan dalam pembuatan tax planning, seharusnya membina wajib pajaknya untuk berjalan sesuai aturan dan menghindari halhal menyimpang seperti menggelapkan omset yang dimana hal tersebut telah menyimpang dari peraturan dan mengarah ke tax evasion. Namun, kenyataannya hal tersebut kerap dilakukan wajib pajak, namun konsultan memiliki rasa simpati terhadap wajib pajak dan ini menyebabkan dilema seperti yang diungkapkan informan $\mathrm{W}$ sebagai berikut saat peneliti bertanya mengenai pengalamannya dalam melakukan tax planning:

“Kalau berbicara tax planning...tax planning itu...kalo murni-murni konsultan pasti subsatnsi sama legalnya di pahami betul, harus benar-benar dimatchingkan...tapi masih banyak yang belum kesana gek he...he...tapi kalo berbicara tax planning pengalaman saya klien itu ya dari dulu sampai sekarang yang saya tangani pasti mungkin hanya $10 \%$ yang riil dan ini terkadang menyebabkan dilema"

Peneliti mendapatkan noema yaitu [pasti mungkin hanya $10 \%$ yang riil dan ini terkadang menyebabkan dilema]. Dari pernyataan noema informan K. D tersebut peneliti berusaha untuk mendalami lagi pernyataan informan sehingga mendapatkan noesis sebagai berikut:

"saya pernah ada nanganin klien besar besar sekali itu gek, tapi omsetnya cuma 10 miliyar dulu, wah ngikutin terus maunya, planning terus, dilema gek...Dilemanya juga kita tau riilnya, berapa omset riilnya, dilema banget sebenernya kita...etis gak kita? Kita gak etis gek...tapi kita juga melihat kondisi dari klien...alasannya dia apa...memang itu hal yang melanggar tapi kita juga memahami kondisi klien...dilemanya disana..."
Noema yang diperoleh dari pernyataan awal Informan $\mathrm{W}$ adalah [pasti mungkin hanya $10 \%$ yang riil dan ini terkadang menyebabkan dilema]. Noema tersebut kemudian peneliti mendalami lagi sehingga memperoleh noesis dilema dirasakan informan $\mathrm{K}$. D ketika Ia mengetahui riilnya namun Ia juga memahami kondisi klien. Dari noema dan noesis tersebut peneliti menarik eidetic reduction dimana Infroman K. D mengetahui bahwa kliennya memberikan data yang tidak benar, hal ini menyebabkan dilema. Informan K. D mengetahui bahwa tindakannya merupakan tindakan yang tidak etis dan melanggar, namun di sisi lain konsultan pajak memiliki rasa simpati terhadap klien sehingga menyebabkan informan K. D ada dalam dilema.

Hal serupa juga di ungkapkan oleh Informan W saat peneliti menanyakan pengalamannya dalam melakukan tax planning, hingga peneliti memperoleh noema dari pernyataan Informan W sebagai berikut:

"Saya punya pengalaman ya yang menyebabkan saya bingung...dilema lah hehe...gini...ada klien saya satu udah lama sama saya kan saya tau ya pergerakannya dan mulai-mulai agak sedikit bandel...jadi... dia itu ya mulai ngasi data omset yang tidak benar ke saya...melaporkan yang tidak sesuai kebenarannya..."

Pernyataan informan $\mathrm{W}$ memunculkan dua noema yaitu [ngasi data omset yang tidak benar ke saya..melaporkan yang tidak sesuai kebenarannya] dan [menyebabkan saya bingung..dilema lah hehe]. Peneliti menggali lebih dalam lagi mengenai pernyataan informan $\mathrm{W}$, sehingga mendapat noesis sebagai berikut:

"kadang kan klien ada juga yang sembunyi dari kita ya, kita juga kan gak pingin tau ya urusan omsetnya, ada juga yang memang mau terbuka riil omsetnya...dan saya sih orangnya fleksibel aja ya tetap saya kasi tau resikonya ini itu,tapi ya saya juga paham kondisi klien, lihat dia adalah niat melapor tapi kondisi aja yang dia jadi gak bisa gitu kan ya...ya kasian juga kan...apa lagi udah lama sama saya...jadi saya bantu dulu..memang dilema takut resiko juga."

Noema dari pernyataan awal Informan W yang menyatakan bahwa [ngasi data omset yang tidak benar ke saya..melaporkan yang tidak sesuai kebenarannya] memunculkan noesis yaitu informan W mengungkapkan terkadang kliennya ada yang sembunyi dari dirinya dalam artian menyembnyikan omsetnya. Informan W mengungkapkan dirinya seorang yang fleksibel dan memahami kondisi klien. 
Namun dalam pernyataannya juga memunculkan noema [menyebabkan saya bingung..dilema lah hehe], sehingga peneliti menarik eidetic reduction yaitu Informan $\mathrm{W}$ mengetahui bahwa kliennya melaporkan data yang tidak sesuai dengan kebenarannya. Hal tersebut diketahui karena informan $\mathrm{W}$ memprediksi setiap pergerakan omset dari kliennya. Informan melihat adanya niat melapor dari klien meskipun tidak sesuai omset, disisi lain informan $\mathrm{W}$ tahu bahwa itu beresiko, tetapi informan W memiliki rasa kasihan terhadap kliennya. Hal tersebut membuatnya berada didalam dilema.

Bentuk Dilema: Kelangsungan Bisnis Jasa Konsultan Pajak. Kelangsungan bisnis bagi setiap perusahaan atau pembisnis sangatlah penitng. Begitu pula dengan konsultan pajak. Konsultan pajak saat ini bisa disebut sebagai suatu perusahaan bisnis. Tidak dipungkiri bahwa saat ini sudah muncul banyaknya konsultan pajak baik yang terdaftar maupun tidak. Banyaknya tugas yang ditawarkan membuat konsultan pajak tidak bisa berdiri sendiri. Konsultan pajak kerap mendirikan kantor konsultan pajak atas nama dirinya ataupun nantinya akan menggandeng konsultan pajak lainnya untuk menjadi rekanan. Konsultan pajak pun memilki karyawan untuk membantunya dalam melakukan tugas-tugasnya. Maka dari itu, konsultan pajak membutuhkan klien untuk melangsungkan kantor konsultan pajaknya. Dimana ia harus memikirkan untuk dirinya sendiri, menggaji karyawan, dan membayar sewa tempat untuk kantornya.

Permasalahan lain muncul pada kode etik yang dipegang teguh oleh konsultan pajak. Konsultan pajak yang terdaftar (dalam IKPI) mempunyai suatu aturan dalam kode etik, yaitu pada Pasal 10 kode etik konsultan pajak menyebutkan bahwa konsultan pajak dilarang untuk memasang iklan. Peraturan tersebut membuat konsultan pajak lebih mementingkan kliennya agar tidak kabur sehingga kelangsungan kantornya dapat stabil. Namun, permintaan klien terkadang menekan konsultan pajak untuk sedikit menyimpang dari aturan yang dipegang teguh. Hal ini menimbulkan suatu dilema seperti yang diungkapkan oleh Informan R.D berikut ini:

"Tax planning...itu susah-susah gampang...yang susah ya pas awal-awal dulu sih, jadi kan tax planning harus sesuai aturan ya, kalo salah dikit bisa melanggar...dulu itu saya rasakan waktu awal-awal jadi konsultan gek, disisi lain mikir nyari klien, kalo klien saya ilang...kabur gitu...ya gak bisa jalan...”.
Melalui pernyataan yang diungkapkan oleh Informan R.D diperoleh beberapa noema yaitu [dulu itu saya rasakan waktu awal-awal jadi konsultan gek] dan [disisi lain mikir nyari klien, kalo klien saya ilang..kabur gitu..ya gak bisa jalan]. Noema tersebut peneliti gali lebih dalam lagi sehingga mendapatkan noesis sebagai berikut:

"Jadi begini... kalo umpama konsultan keras sama aturan kan tax planning harus sesuai aturan dan klien kan bedabeda ya terkadang mintanya aneh-aneh sampai kearah menggelapkan omset juga, kalau kita keras dan klien kabur, nanti incomenya kurang, kalo dia mengikuti, ya beresiko...jadi dilema..."

Noema yang diperoleh dari pernyataan informan R. D yaitu [dulu itu saya rasakan waktu awalawal jadi konsultan gek] dan [disisi lain mikir nyari klien, kalo klien saya ilang..kabur gitu..ya gak bisa jalan] memunculkan noesis dimana informan R. D mengungkapkan bahwa klien akan kabur jika konsultan pajaknya terlalu keras dalam memegang aturan. Hal tersebut menyebabkan income yang diperoleh konsultan menjadi berkurang, dan ini menyebabkan informan R.D mengalami dilema.

Diperolehnya noema dan noesis dari pernyataan Informan R. D dapat ditarik eidetic reduction yaitu informan $\mathrm{R}$. Dmerasakan suatu dilema saat awal-awal dirinya menjadi konsultan pajak. Informan R. D dalam membuat tax planning menyadari harus sesuai dengan aturan, namun jika ia keras dalam memegang aturan kliennya akan kabur. Hal ini terjadi dikarenakan klien mempunyai sifat yang berbeda-beda, ada yang tidak melaporkan omset secara riil dengan cara menggelapkan data keuangan. Informan R. D mengetahui bahwa hal tersebut merupakan hal yang menyalahi aturan, tetapi di sisi lain informan R. D memikirkan kelangsungan bisnisnya dengan ia menyatakan bahwa jika klien kabur, maka pendapatannyanya akan berkurang. Hal tersebut membuatnya berada dalam situasi dilema.

Hal serupa juga diungkapkan oleh informan W saat peneliti menanyakan mengenai pengalamannya dalam menjalankan tax planning untuk kliennya, sehingga peneliti memperoleh noema sebagai berikut:

"Pengalaman saya sih ya.. dalam tax planning saya sering galau haha..galau menghadapi klien itu..contohnya aja ya pasti ada yang gak mau 
rill.. ya saya tetep mau bantu sih cuman kan itu melanggar ya.. Konsultan lain ada sih yg saklek, bener-bener gak mau kalo gak riil..., mungkin dia banyak duit kalik he..he... jadi dia gak perlu klien kan gitu"

Pernyataan informan $\mathrm{W}$ memunculkan beberapa noema yaitu, [galau menghadapi klien itu], [Konsultan lain ada sih yg saklek, bener-bener gak mau kalo gak riil], [mungkin dia banyak duit kalik he..he.. jadi dia gak perlu klien kan gitu]. Noemanoema tersebut peneliti gali lebih dalam lagi sehingga mendapatkan noesis:

"Ya...gak bisa dipungkiri ya dik...jaman sekarang klien kan mencari orang yang bisa membantunya, kita juga dapat uang dari klien...jadi kita juga pasti memikirkan income...jelas itu dik...cuman satu sisi emang seharusnya ktia itu saklek seperti itu kok, itu yang benar...tapi kalau sepi bagaimana...itu galaunya dik..."

Noema yang diperoleh dari pernyataan Informan W mendapatkan noesis yaitu Informan W mengungkapkan bahwa klien mencari konsultan yang dapat membantunya dalam menyelesaikan masalah perpajakannya. Ia mengibaratkan konsultan yang taat memegang aturan adalah suatu hal yang benar. Namun informan W juga mengungkapkan bahwa dirinya juga memikirkan income yang ia dapatkan dari kliennya.

Berdasarkan noema dan noesis yang di peroleh dari pernyataan informan, peneliti menarik eidetic reduction yaitu informan $\mathrm{W}$ mengungkapkan dirinya sering dilanda kebingungan saat melakukan tax planning. Ia menyebutkan bahwa dirinya mau membantu klien walaupun klien memberikannya data yang tidak riil, berbeda dengan konsultan pajak yang keras dalam memegang aturan. Menurutnya, klien saat ini mencari konsultan pajak yang bisa membantunya. Konsultan pajak juga mendapatkan pemasukan untuk bisnis jasanya tentunya dari kliennya tersebut. Ia juga menyadari bahwa sebagai konsultan pajak memang seharusnya untuk bersikap keras dalam memegang aturan sehingga tetap berada di jalan aturan, namun disisi lain ia juga mempertimbangkan kondisi bisnisnya, hal ini menyebabkan ia dilanda kebingungan yang mendalam.

Pengalaman mengatasi dilema: Membangun kesadaran wajib pajak sebagai klien. Sesuai dengan fungsinya sebagai seorang konsultan pajak dimana harus membina wajib pajak untuk patuh terhadap peraturan dan tentunya membangun kesadaran wajib pajak dalam hal perpajakan. Wajib pajak memiliki sifat dan permintaan yang berbeda. Fakta dilapangan wajib pajak kerap meminta konsultan pajak untuk membantunya melakukan tax planning, namun dengan data omset yang tidak riil. Hal tersebut merupakan suatu pelanggaran dan mengarah ke tax evasion. Namun di sisi lain, konsultan pajak juga memiliki kepedulian kepada wajib pajaknya dengan melihat kondisi dari perusahaan wajib pajak, hal-hal yang menyebabkan wajib pajaknya menggelapkan omset. Hal ini menyebabkan konsultan pajak berada dalam dilema.

Konsultan pajak melihat hal ini harus mempunyai suatu pertimbangan yang etis untuk mengubah pola pikir wajib pajak serta membebaskannya dari rasa dilema. Seperti yang diungkapkan oleh informan K. D sebagai berikut:

"berbicara menyembunyikan omset...tipikal klien nakal sudah pasti ada, tapi kita hanya membina, ayo, tax planning kita kasi tau yang bener, ya kita tau lah udah banyak yg disembunyikan kita terima-terima aja gitu lo, bukan berarti kita nolak, tapi bukan berarti kita keputusan nerima dengan alasan uang gek..."

Noema yang diperoleh dari pernyataan informan K. D adalah [ya kita tau lah udah banyak yg disembunyikan kita terima-terima aja gitu lo, bukan berarti kita nolak, tapi bukan berarti kita keputusan nerima dengan alasan uang gek]. Pernyataan informan K. D memunculkan keinginan peneliti untuk mendalaminya lagi sehingga diperoleh noesis sebagai berikut:

"saya itu liat klien yang mau belajar, ada keinginan untuk memahami, Dikatakan memang engga etis, tapi disini saya punya tujuan yaitu mau agar bagaimana klien memahami kesalahannya...karena kita meyakini, yang akan membentuk mereka adalah periode waktu... fenomena ini banyak terjadi dilapangan dan gak bisa dipungkiri gek... cara mengatasi dilema ini ya pahami dulu situasinya... kalau bahasa gampangnya gini gek, kayak curhat, kita dengerin kita turutin maunya dulu, tapi pelanpelan kita berikan pemahaman jadi wpnya paham, dia kesadaran sendiri setelah ktia berikan informasi aturan, masukan-masukan, nanti periode waktu dia sendiri yang mau.." 
Diperolehnya noema dan noesis dari pernyataan informan $\mathrm{K}$. D dapat ditarik eidetic reduction yaitu informan $\mathrm{K}$. D dalam pengalamannya mengatasi dilema adalah dengan tetap membina kliennya dengan tujuan membangun rasa kesadaran dari kliennya bukan karena tujuan uang semata. Informan K. D mencari klien meyakinkan bahwa periode waktu akan membentuk kesadaran klien. Membentuk kesadaran klien dilakukan dengan menggunakan suatu taktik dimana informan K. D mengibaratkan seperti 'curhat', ia akan mendengarkan kliennya, mengikuti keinginannya klien, memahami keinginan klien, namun sedikit demi sedikit secara halus, ia akan membina klien hingga menimbulkan rasa kepedulian klien terhadap perpajakan. Sehingga klien tersebut akan berubah dengan mulai melaporkan data-datanya secara riil dan dilema yang dirasakan infroman K. D pun dapat menghilang.

Selain hal tersebut, konsultan pajak juga dapat mengatasi dilemanya dengan membuat suatu kontrak seperti yang diungkapkan informan $\mathrm{W}$ sebagai berikut:

"Pengalaman saya ya buat atasin dilema... saya kalau saya mau cuci tangan kan bisa aja... Saya sih mau sih suruh aja okay saya bantu lapor aja dulu kita tambah-tambahin biaya aja dulu, nanti kita akalin pakai buat pembetulan kalau udah punya uangnya..."

Peneliti menemukan noema dari pernyataan Informan $\mathrm{W}$ yaitu [cuci tangan], peneliti menggali kembali dan menemukan noesis:

"jadi saya bilang dikontrak data yang kamu kasi ke saya, saya hitungkan aja... Ya bahasa kasarnya kan gitu ya...bahasa dikontrak apa gitu halusnya kan ada...bahasa kasarnya apa yang kamu kasi saya itungkan gitu aja sih saya jadi kalau beresiko dikemudian hari saya gak tanggung jawab...nanti klien kan juga sadar ya..ngerasa gitu dia takut...dia kalau udah ada uang dengan adanya kontrak itu kan pasti dia bayar...kan niat awalnya begitu artinya dia ada kesadaran dong...kalau dia bohong itu ya resikonya..ibarat saya sudah baik kasihan sama dia, tapi saya dibohongin ya gimana...biarin aja resikonya...he...he...yang penting satu kalo saya, kalau seumpama kliennya gajah jangan ngaku semut...itu aja, kalau pun dia bohong, dia bakal takut sendiri, kan dia uda tanda tangan kontrak yang tadi itu...ya itu jadi dilema sih berkurang ya.."
Berdasarkan noema dan noesis yang diperoleh dari pernyataan informan $\mathrm{W}$, peneliti menarik suatu eidetic reduction yaitu informan $\mathrm{W}$ dalam pengalamannya mengatasi dilema adalah dengan memberikan suatu kontrak kepada kliennya. Kontrak tersebut berisikan bahwa data-data yang diberikan klien ke informan semua dianggap benar. Hal ini menyebabkan jika klien terkena resiko, maka informan W tidak akan terkena resiko karena kontrak telah disetujui oleh klien. Informan W menjelaskan bahwa dengan adanya kontrak tersebut klien akan menjadi takut jika mempunyai niat ingin berbohong dengan mengatakan tida memiliki uang untuk membayar pajak sehingga pajak yang dilaporkan tidak riil. Informan W menegaskan kliennya seumpama gajah jangan mengaku sebagai semut. Informan W juga menyebutkan bahwa dilemanya dapat berkurang dengan menetapkan suatu kontrak.

Pengalaman mengatasi dilema: Kesadaran Profesi. Menjalani sebuah profesi, seseorang harus memiliki komitmen atas moral yang tinggi untuk mematuhi aturan. Aturan dalam sebuah profesi atau yang biasa disebut kode etik digunakan sebagai pedoman untuk menjalankan suatu profesi. Setiap profesi harus menaati kode etik dalam menjalankan tugasnya sebagai pemberi jasa pelayanan kepada masyarakat. Profesi konsultan pajak pun demikian. Konsultan pajak dalam memberikan jasa konsultasi kepada kliennya terikat pada aturan kode etik yang telah di tetapkan. Kode etik mengharuskan konsultan pajak menjunjung tinggi integrias dan bersikap professional dalam menjalankan tugasnnya (Maulidya, 2016). Namun, yang terjadi di lapangan konsultan pajak terkadang merasakan suatu dilema dalam menjalankan tugasnya terutama terkait dengan tax planning. Dilema yang dihadapi saat melakukan tax planning mempunyai banyak faktor seperti rasa simpati kepada klien, adanya peraturan yang "abuabu" hingga faktor imbalan yang dibayarkan klien.

Disinilah peran dari prinsip yang dipegang oleh masing-masing konsultan pajak. Prinsip yang dipegang oleh konsultan pajak haruslah berlandaskan dengan aturan yang berlaku. Jika konsultan pajak sudah memegang teguh prinsip harus menaati aturan, dilema yang dirasakan dapat diminimalisir. Konsultan pajak dalam melakukan tax planning haruslah memegang prinsip untuk tetap sesuai dengan aturan yang berlaku. Seperti pengalaman yang diungkapkan oleh informan $\mathrm{M}$ berikut ini: 
"kalau kita melakukan efisiensi tax planning itu yang pertama tidak boleh melanggar aturan, jadi memang dari sisi klien menganggap tidak maksimal, karena kita juga gak mau terlalu frontal kan, ya terlalu berani lah karena pasti menyalahi aturan, plus saya juga gak mau terlalu merugikan negara"

Pernyataan yang diungkapkan oleh Informan M membuahkan beberapa noema yaitu [tidak boleh melanggar aturan, jadi memang dari sisi klien menganggap tidak maksimal] dan [plus saya juga gak mau terlalu merugikan negara]. Noema yang diperoleh kemudian peneliti dalami lagi sehingga memperoleh noesis:

"Ya...jadi yang diambil yang di tengah-tengah artinya selama penghematan itu sesuai aturan dan tidak merugikan negara, dan tidak terlalu beresiko nanti kalo ada diperiksa oleh orang pajak dikemudian hari...kalau dalam hal ngumpetin omset selama dia tidak terlalu signifikan, mungkin saya masih bisa toleransi ya...kalo selebihnya saya gamau, karena resiko, nanti dia juga diperiksa... Namanya warna negara harus mempunyai nasionalisme, kapan negara bisa maju jika kaya gitu terus... dan saya sih intinya satu aja, dimana kita tinggal kita harus bayar pajak gak bisa enggak, kalo enggak Indonesia gak akan maju-maju...intinya juga bagi saya tetap aja berjalan dalam aturan, dilema itu tidak akan dirasakan."

Noema dan noesis yang diperoleh dari pernyataan pengalaman informan $M$ dapat ditarik eidetic reduction yaitu informan $\mathrm{M}$ berpendapat bahwa jika melakukan tax planning tidak boleh melanggar peraturan perpajakan. Walaupun di sisi klien menganggap tidak maksimal, namun ia tetap berprinsip tidak ingin menyalahi aturan dan tidak ingin terlalu merugikan negara. Ia memberikan toleransi kepada kliennya dalam hal menyembunyikan omset. Ia mengatakan bahwa jika tidak terlalu signifikan, ia masih mau untuk menerima, jika terlalu frontal dan berani ia akan menolak kliennya. Informan $M$ juga mempunyai rasa nasionalisme, Ia menyadari bahwa negara tidak akan maju jika rakyatnya malas untuk membayar pajak. Ia juga menegaskan jika berjalan sesuai dengan peraturan, dilema pasti tidak akan dirasakan.

Selain memiliki prinsip tetap sesuai aturan dan juga harus mempunyai rasa nasionalisme, dalam hal menggait klien informan $\mathrm{K}$. R mengungkapkan pendapatnya sebagai berikut:

"Sebenernya di ikatan itu kita kita diajarkan jangan menghalalkan segala cara untuk mendapatkan klien, jangan takut kehabisan klien, karena klien yg mencari kita..."

Pernyataan Informan K. R diperoleh noema yaitu [jangan takut kehabisan klien, karena klien yg mencari kita]. Peneliti mendalaminya lagi sehingga memperoleh noesis:

"Gini ya di ikatan, ya diketahui lah ya konsultan pajak memang takut kehilangan kliennya bahkan menyebabkan dilema, tapi saat ini saya meyakinkan diri gak bakal kehabisan klien..ibarat gini, dibali konsultan pajak cuman 150 konsultan, wp dibali berapa dik? Banyak ribuan..jadi sih saya yakin kalo dia gak cocok sama saya dan gak bisa di bina ya lepas aja..dari pada saya bingung dan dilema"

Noema dan noesis yang diperoleh dari pernyataan pengalaman informan $\mathrm{K}$. R, peneliti menarik eidetic reduction yaitu informan K.R melalu pengalamanya mengatakan bahwa untuk tidak takut kehabisan klien, karena klien yang membutuhkan konsultan pajak. Ia memberikan contoh konsultan pajak di Bali yang terdaftar hanya 150 konsultan sedangkan wajib pajak yang ada di Bali ribuan, sehingga jika ia merasa tidak ada kecocokan dengan kliennya, untuk mengatasi kebingungan dan menghindarinya dari dilema, maka ia akan melepas kliennya tersebut.

Sintesis Penelitian: Meningkatkan Kesadaran Profesi Konsultan Pajak Dan Membangun Kesadaran Wajib Pajak Guna Meminimalisir Rasa Dilema. Tidak dipungkiri bahwa konsultan pajak kerap merasakan dilema dalam melakukan tugasnya salah satunya dalam pembuatan tax planning. Konsultan pajak harus menaati peraturan dan memegang teguh kode etik meskipun dihadapannya terdapat berbagai macam 'godaan' yang ia hadapi. Konsultan pajak harus menyadari bahwa dirinya merupakan salah satu tangan aparatur pajak terdekat dengan wajib pajak sehingga konsultan pajak sangat berfungsi untuk membangun kepatuhan wajib pajak. Berbagai macam 'godaan' dari wajib pajak seperti imbalan yang akan diberikan membuat konsultan pajak berada dalam suatu rasa kebingungan antara harus mengikuti keinginan wajib pajak atau harus tetap memegang aturan dan membina wajib pajak. Hal ini menyebabkan Konsultan pajak dapat terbebas 
dari dilema dengan menyadari perannya sebagai kaki tangan aparatur perpajakan untuk membantu wajib pajak dalam masalah-masalah pajak yang dihadapi serta untuk membina wajib pajak guna membangun kesadaran wajib pajak. Konsultan pajak harus memahami secara baik aturan-aturan yang digunakan dalam pembuatan tax planning agar tidak menyimpang dari aturan untuk menghindarinya dari resiko di kemudian hari. Selain itu, konsultan pajak harus membangun prinsip yang kuat untuk tidak melanggar peraturan. Meyakinkan dirinya untuk tetap dalam bingkai kode etik serta meyakinkan diri bahwa tidak akan sulit mendapatkan wajib pajak sebagai 'klien'.

Meyakinkan diri memegang teguh peraturan akan membuat konsultan pajak lebih tegas dalam menangani wajib pajaknya. Konsultan pajak juga harus membangun kesadaran wajib pajak. Membangun kesadaran wajib pajak dapat dilakukan terlebih dahulu dengan membangun rasa kepedulian wajib pajak terhadap sistem perpajakan. Membuat wajib pajak memahami bagaimana arti pajak dalam suatu Negara. Meskipun membutuhkan periode waktu yang tidak singkat, diharapkan dengan membangun rasa kepedulian wajib pajak dapat meningkatkan kepatuhannya. Wajib pajak menjadi peduli dan patuh akan pajak membuat konsultan pajak terbebas dalam dilema. Konsultan pajak dapat melakukan tax planning sesuai dengan bingkai peraturan tanpa ada 'tekanan' yang diberikan oleh wajib pajak.

Pemerintah dalam hal ini juga berperan dalam meningkatkan kepedulian wajib pajak. dengan membuat suatu kebijakan guna untuk meningkatkan kesadaran wajib pajak. Pemerintah dapat lebih transparan mensosialisasikan manfaat apa saja yang akan diperoleh wajib pajak jika membayar pajak. Pemerintah harus meyakinkan wajib pajak bahwa pajak yang dibayarkan dipergunakan sepenuhnya untuk pembangunan Negara. Selain itu, pemerintah dapat membuat kebijakan mengenai pemeriksaan dan pelaporan skema tax planning yang dilakukan oleh wajib pajak guna mengetahui apakah tax planning yang dilakukan masih di didalam bingkai peraturan. Tidak hanya perusahaan wajib pajak yang tercantum dalam skema tetapi juga tercantum nama konsultan pajak. Sehingga kebijakan pemeriksaan skema tax planning tidak hanya untuk wajib pajak tetapi juga berpengaruh terhadap konsultan pajak. Dengan demikian, wajib pajak akan lebih memperhatikan aturan perpajakan dan konsultan pajak akan lebih memperkuat integritasnya dalam berjalan sesuai peraturann konsultan pajak harus memikirkan untuk membuat suatu pertimbangan yang etis guna untuk membebaskan dirinya dari rasa dilema.

\section{SIMPULAN}

Konsultan pajak dalam melakukan tax planning kerap diliputi rasa dilema. Walaupun kerap merasakan dilema saat melakukan tax planning, konsultan pajak selalu mencari cara agar tetap menjaga profesionalitasnya sebagai seorang konsultan pajak dan terlepas dari rasa dilema yang konsultan pajak rasakan. Dilema yang muncul akibat dari beberapa faktor seperti konsultan pajak memiliki rasa simpati terhadap kliennya, konsultan pajak merasa takut akan kehilangan klien karena berkaitan dengan income yang akan diperoleh. Namun, dilema tersebut dapat konsultan pajak atasi dengan membuat suatu pertimbangan etis. Konsultan pajak dalam pengalamannya mempunyai berbagai macam pertimbangan untuk mengatasi dilema yang dirasakan, seperti membangun kepatuhan wajib pajak dengan meningkatkan kesadaran wajib pajak dan konsultan pajak harus mempunyai kesadaran profesi dengan meyakinkan dirinya untuk selalu berpegang teguh prinsip menaati aturan apapun kondisinya. Berjalan sesuai aturan akan menghindarinya dari resiko di kemudian hari, serta menghindarinya dari rasa dilema.

Berdasarkan hasil penelitian ini membuahkan saran untuk penelitian selanjutnya. Masih terbatasnya jumlah penelitian tentang konsultan pajak dengan menggunakan metodelogi kualitatif, peneliti berharap dengan adanya penelitian ini dapat membangun sebuah ide untuk membuat penelitian selanjutnya tentang konsultan pajak dengan menggunakan studi lainnya namun masih dalam lingkup kualitatif ataupun menambah jumlah informan sehingga mendapatkan hasil yang lebih beragam dan lebih dalam.

\section{REFERENSI}

Creswell, J. W. (2016). Qualitative Inquiry \& Research Design: Choosing Among Five Approaches (5th ed.). California: Sage Publication.

Erard, B. (1993). Taxation with Representation: An Analysis of The Role of Tax Practitioners in Tax Compliance. Journal of Public Economics, 52(2), 163-197.

Fitriani, E. I. (2014). Makna Harga Diri Pada Remaja Putri Yang Melakukan Hubungan Seksual Pranikah Di Pekanbaru. Universitas 
Islam Negeri Sultan Sarif Kasim Riau.

Frecknall-Hughes, J., \& Krichler, E. (2015). Towards a General Theory of Tax Practice. Social \& Legal Studies, 24(2), 289-312.

Katuuk, D., Manossoh, H., \& Walandouw, S. K. (2017). Pengaruh Integritas Dan Kreativitas Konsultan Pajak Terhadap Kepatuhan Wajib Pajak. Jurnal Riset Akuntansi Going Concern, 12(2), 1-8.

Kuswarno, E. (2009). Metode Penelitian Komunikasi Fenomenologi. Bandung: Widyapadjajaran.

Mangoting, Y. (2017). Menguak Dimensi Kecurangan Pajak. Jurnal Akuntansi Multiparadigma (JAMAL), 8 (2), 227-429.

Massie, J. M. (2017). Pengaruh Etika Profesi, Religiusitas dan Kompetensi Terhadap Pengambilan Keputusan Etis Konsultan Pajak. Universitas Kristen Maranatha.

Maulidya, D. (2016). Dilema Etik Sebagai Konsultan Pajak. Retrieved from http://debbymau lidya.blogspot.com/2016/12/dilema-etik-sebagaikonsultan-pajak.html

Noviriani, E. (2015). Studi Fenomenologi Atas Dilema
Etis Auditor Internal Pemerintah. Ekuitas: Jurnal Ekonomi Dan Keuangan, ISSN 1411.

Putu, W. P. (2009). Konstruksi Gender. Universitas Indonesia.

Sanders, P. (1982). Phenomenology/ : A New Way of Viewing Organizational Research. The Academy of Management Review, 7(3), 353-360.

Suardika. (2016). Desain Pembelajaran Dengan Pendekatan Siklus Belajar (learning Cycle). Retrieved from https://aritmaxx.wordpress.com/ 2016/10/17/desain-pembelajaran-denganpendekatan-siklus-belajar-learning-cycle/

Suryowati, E. (2016). Apa Perbedaan Praktik Penghindaran Pajak dan Penggelapan Pajak? Retrieved from https://bisniskeuangan. kompas. com/read/2016/04/14/083000826/Apa. Perbedaan.Praktik.Penghindaran.Pajak.dan. Penggelapan.Pajak.

Windesi, E. M. (2016). Pengaruh Faktor Individu: Persepsi Pentingnya Etika Dan Tanggung Jawab Sosial, Machiavellianism, Dan Locus of Control Terhadap Pengambilan Keputusan Etis Akuntan Pajak Dalam Perencanaan Pajak (Tax planning). Universitas Brawijaya. 